\title{
Effect of Agronomic Practices and Weed Management Practices on Weed Dry Weight and Weed Control Efficiency in Direct Seeded Rice under Rainfed Condition of Eastern Uttar Pradesh, India
}

\author{
Gargi Goswami ${ }^{1}$, Yashwant Singh ${ }^{1}$ and Santosh Kumar ${ }^{2^{*}}$ \\ ${ }^{1}$ Department of Agronomy, Institute of Agricultural Sciences, BHU, Varanasi-221 005, India \\ ${ }^{2}$ Department of Agronomy, Regional Research Station, BAU, Sabour- 852201, India \\ *Corresponding author
}

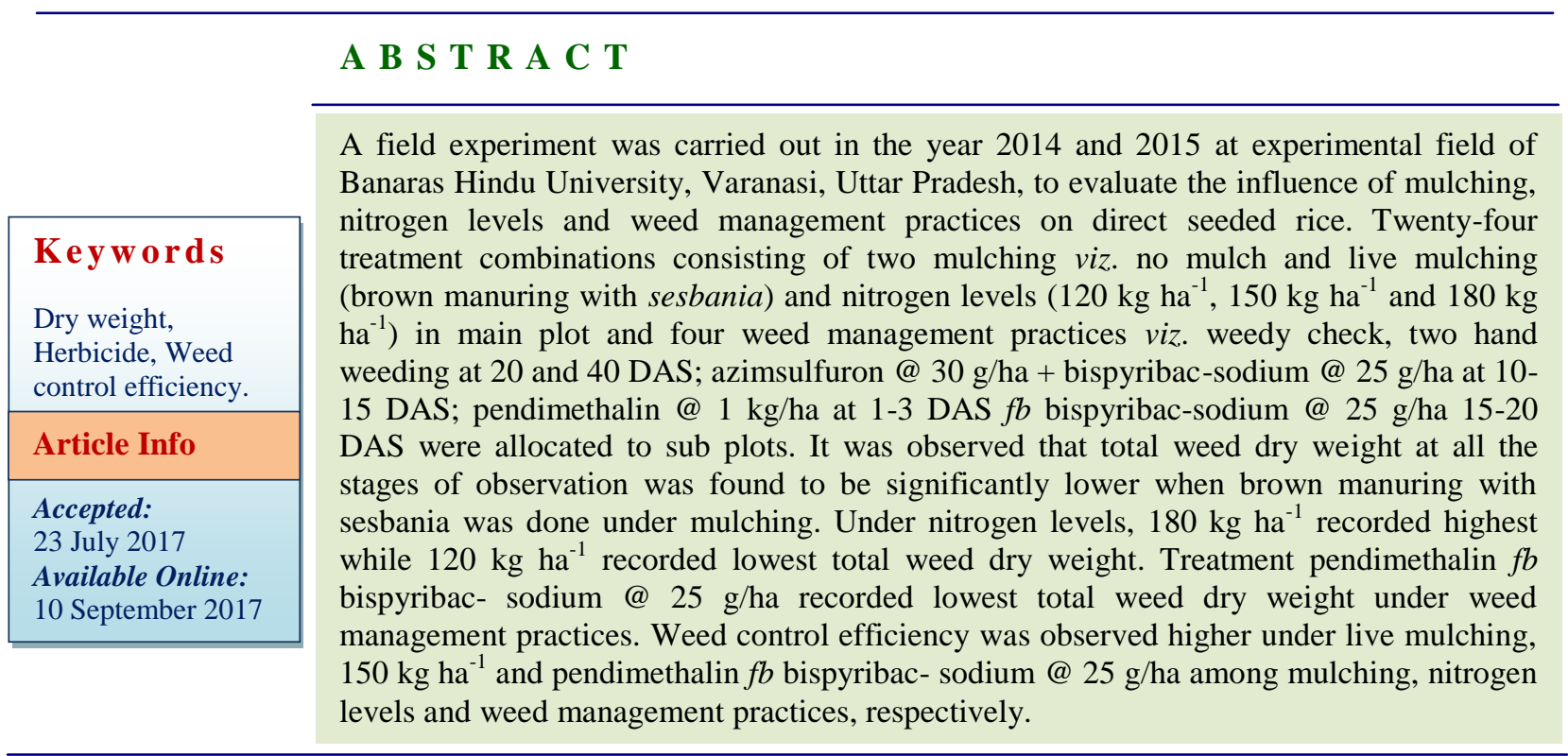

\section{Introduction}

Rice (Oryza sativa L.) is the most important and extensively grown cereal crop in tropical and subtropical regions of the world. Globally, total rice consumption was recorded 477.4 million metric tonnes in 2013-14 (Anonymous, 2015). It is grown on approximately $163 \mathrm{~m}$ ha out of which $145 \mathrm{~m}$ ha is in Asia (Anonymous, 2013). Ninety per cent of the world's rice is produced as well as consumed in Asia (Solunke et al., 2006). The demand for food grains in India is increasing day by day and the requirement by the year
2025 is estimated to be increased by 40 per cent as compared to 2003-04. To sustain present food self-sufficiency and to meet future food requirements, there is need to increase rice productivity by 3 per cent per annum. The possibility of expanding the area under rice in near future is limited. Therefore, this extra rice production needed has to come from a productivity gain. The major challenge is to achieve this gain with less water, labour and chemicals, thereby ensuring long-term sustainability. To preserve natural resources 
especially water, there is a need to replace puddled transplanted rice with the directseeding technology.

Direct seeded methods have several advantages over transplanting (Singh et al., 2005). In addition to higher economic returns, direct seeded rice crops are faster and easier to plant, less labour intensive, consumes less water (Jehangir et al., 2005; Bhushan et al., 2007) and are conducive to mechanization (Chauhan, 2012) generally flower earlier leading to shorter crop duration (Farooq et al., 2006), mature 7-10 days earlier and have less methane emissions (Balasubramanian and Hill, 2002) than transplanted rice.

High weed infestation is a major constraint for broader adoption of direct seeded rice (Rao et al., 2007). They are the prime yield limiting biotic constraints that compete with rice for moisture, nutrients and light. Weed competition reduced the grain yield by 50 $60 \%$ in direct seeded rice.

Any delay in weeding will lead to increased weed biomass which has a negative correlation with yield. However, the magnitude of loss in yield in direct seeded rice depends upon the density of weeds, type of weed species and duration of presence of weeds.

The use of only one method of weed control in a DSR crop may not be successful for raising a good crop. Manual weeding has become difficult because of labour scarcity and increased cost. Chemical control is the most effective, economic and practical way of weed management (Marwat et al., 2006; Hussain et al., 2008) during periods of labour shortage when weeding coincides with other farm work. Application of pre-emergence herbicides is an effective method for controlling weeds in the early stages (Subbaiah, 2008). Post emergence herbicides will be required to tackle the weed flushes at later stages. Use of pre-emergence herbicides have been found effective in initial stages, but the second flush of weeds at 20-25 days after sowing becomes a problem. Moreover, application of pre-emergence herbicides is very conditional and requires its application within 3-5 days of sowing, which is a very short and busy period for farmers and many times coincides with continuous rains or drought. Therefore, success of direct seeded rice depends largely on effective weed control especially with post-emergence chemical methods. Therefore crop management technologies that help to reduce the competitive effects of weeds on crops and economical are needed.

\section{Materials and Methods}

The experiment was laid out in split-plot design with three replications. The mulching (no mulch and live mulch i.e. brown manuring with sesbania) and nitrogen doses $\left(120,150\right.$ and $\left.180 \mathrm{~kg} \mathrm{ha}^{-1}\right)$ were assigned to main plots and weed management practices (weedy; two hand weeding at 20 and 40 DAS; azimsulfuron@30 g/ha + bispyribac-sodium @ 25 g/ha at 10-15 DAS; pendimethalin@ 1 $\mathrm{kg} / \mathrm{ha}$ at 1-3 DAS fb bispyribac-sodium @ 25 $\mathrm{g} / \mathrm{ha}$ 15-20 DAS) in sub plots. Rice variety Sarjoo 52 was sown in the last week of June.

Seed of sesbania was sown in between rows just after seeding of rice for brown manuring and was knock down at 25 DAS with the help of 2,4 D. Spray of herbicides was done by using knap sack sprayer with flat fan nozzle with their respective doses at appropriate stages.

A uniform dose of $60 \mathrm{~kg} \mathrm{P}_{2} \mathrm{O}_{5}$ and $60 \mathrm{~kg} \mathrm{~K}_{2} \mathrm{O}$ $\mathrm{ha}^{-1}$ was applied in all the treatments through single super phosphate and murate of potash, respectively. Nitrogen doses of 120, 150 and $180 \mathrm{~kg} / \mathrm{ha}$ were given as per treatment 
through urea. Half of total nitrogen and full dose of phosphorus, and potassium were applied to rice crop as basal application before sowing. Remaining half dose of nitrogen in the form of urea was top dressed in two equal splits, at active tillering and panicle initiation stage during both the years.

Weed enclosed in a quadrate of $0.25 \mathrm{~m}^{2}$ were cut at ground level and separated as grasses, sedges and broad leaved weeds at 30 DAS, 60 DAS and 90 DAS, washed with tap water to remove soil and unwanted particles adhering to them, sun dried followed by oven drying at $70^{\circ} \mathrm{C}$ for 48 hours, and then weighed. The total weed dry weight was obtained by adding the weight of these three groups. The dry weight was expressed in $\mathrm{g} \mathrm{m}^{-2}$.

Weed control efficiency (\%) was calculated using the formula given by Tripathy and Mishra (1971).

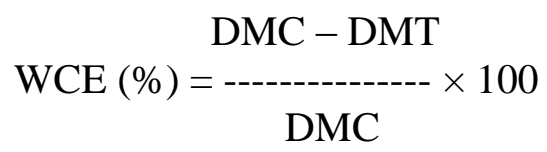

Where,

$\mathrm{WCE}=$ Weed control efficiency

DMC $=$ Dry weight of weeds $\left(\mathrm{g} \mathrm{m}^{-2}\right)$ in unweeded control

DMT $=$ Dry weight of weeds $\left(\mathrm{g} \mathrm{m}^{-2}\right)$ in weed control treatment

WCE was expressed in percentage.

Data on weed dry weight have shown high degree of variation. A relationship between the means and variance was observed. Therefore, the data on weed count and weed dry weight were subjected to $\sqrt{ }(x+0.5)$ transformation to make analysis of variance more valid.

\section{Results and Discussion}

\section{Total weed dry weight $\left(\mathrm{g} \mathrm{m}^{-2}\right)$}

Overall, total dry weight of weeds (Table 1) increased gradually upto maturity under mulching, nitrogen levels and weed management practices. Mulching resulted in significantly lower total dry weight of weeds during both the years. This might be due to smothering effect of dhaincha on weed growth at initial growth stages.

Further, it was observed that total dry weight of weeds was found to be significantly highest with $180 \mathrm{~kg} \mathrm{ha}^{-1}$. This was statistically at par with $150 \mathrm{~kg} \mathrm{ha}^{-1}$ for the years, 2014 and 2015 respectively.

This might be due to application of higher dose of nitrogen which results in higher weed growth along with crop. Significantly lowest total dry weight of weeds at all growth stages during both the years of experiment was recorded with120 $\mathrm{kg} \mathrm{ha}^{-1}$. Similar findings have been reported by Ravisankar et al., (2008).

Under different weed management practices, the best treatment in minimizing total dry weight of weeds was pendimethalin $f b$ bispyribac- sodium @ $25 \mathrm{~g} / \mathrm{ha}$ that was significantly better than rest of treatments at all the stages of crop growth in both the years.

Pre-emergence herbicide pendimethalin controlled the growth of weeds at initial stage while post-emergence herbicide bispyribac checked the weed growth at subsequent flushes. This was followed by two hand weeding (20 and 40 DAS) which was statistically at par with azimsulfuron @ 30 g/ha + bispyribac- sodium @ 25 g/ha treatment. All these treatments recorded significantly lower total dry weight of weeds over weedy check. 
Table.1 Effect of mulching, nitrogen levels and weed management practices on total dry weight of weeds $\left(\mathrm{g} \mathrm{m}^{-2}\right)$ at different growth Stages of direct seeded rice

\begin{tabular}{|c|c|c|c|c|c|c|c|c|}
\hline \multirow[t]{2}{*}{ Treatments } & \multicolumn{2}{|c|}{30 DAS } & \multicolumn{2}{|c|}{60 DAS } & \multicolumn{2}{|c|}{90 DAS } & \multicolumn{2}{|c|}{ At harvest } \\
\hline & 2014 & 2015 & 2014 & 2015 & 2014 & 2015 & 2014 & 2015 \\
\hline \multicolumn{9}{|l|}{ Mulching } \\
\hline \multirow[t]{2}{*}{ No mulch } & 5.58 & 5.85 & 12.63 & 13.39 & 15.04 & 15.73 & 16.48 & 16.49 \\
\hline & $(30.61)$ & $(33.70)$ & $(159.02)$ & $(178.91)$ & $(225.66)$ & $(246.78)$ & $(270.99)$ & $(286.37)$ \\
\hline Live mulch (Brown manuring & 4.51 & 4.54 & 12.10 & 12.38 & 14.22 & 14.68 & 15.48 & 16.04 \\
\hline with Sesbania) & $(19.88)$ & $(20.11)$ & $(145.98)$ & $(152.66)$ & $(201.84)$ & $(215.11)$ & $(239.10)$ & $(256.67)$ \\
\hline SEm \pm & 0.09 & 0.05 & 0.06 & 0.05 & 0.09 & 0.06 & 0.07 & 0.07 \\
\hline $\mathrm{CD}(\mathrm{P}=\mathbf{0 . 0 5})$ & 0.25 & 0.14 & 0.20 & 0.16 & 0.26 & 0.18 & 0.21 & 0.21 \\
\hline \multicolumn{9}{|l|}{ Nitrogen level $\left(\mathrm{kg} \mathrm{ha}^{-1}\right)$} \\
\hline \multirow[t]{2}{*}{120} & 4.71 & 4.86 & 11.68 & 12.17 & 14.18 & 14.67 & 15.18 & 15.75 \\
\hline & $(21.66)$ & $(23.11)$ & $(135.88)$ & $(147.68)$ & $(200.67)$ & $(214.74)$ & $(229.82)$ & $(247.56)$ \\
\hline \multirow[t]{2}{*}{150} & 5.20 & 5.39 & 12.60 & 13.18 & 14.74 & 15.40 & 16.25 & 16.81 \\
\hline & $(26.56)$ & $(28.51)$ & $(158.34)$ & $(173.30)$ & $(216.79)$ & $(236.76)$ & $(263.65)$ & $(282.05)$ \\
\hline \multirow[t]{2}{*}{180} & 5.29 & 5.44 & 12.80 & 13.30 & 14.98 & 15.55 & 16.44 & 16.90 \\
\hline & $(27.52)$ & $(29.11)$ & $(163.29)$ & $(176.38)$ & $(223.80)$ & $(241.36)$ & $(269.69)$ & $(284.96)$ \\
\hline $\mathrm{SEm} \pm$ & 0.09 & 0.05 & 0.06 & 0.05 & 0.09 & 0.06 & 0.07 & 0.07 \\
\hline $\mathbf{C D}(\mathbf{P}=\mathbf{0 . 0 5})$ & 0.25 & 0.14 & 0.20 & 0.16 & 0.26 & 0.18 & 0.21 & 0.21 \\
\hline \multicolumn{9}{|l|}{ Weed management practices } \\
\hline \multirow[t]{2}{*}{ Weedy } & 6.96 & 7.22 & 15.46 & 15.98 & 17.94 & 18.40 & 19.04 & 19.87 \\
\hline & $(47.99)$ & $(51.70)$ & $(238.41)$ & $(254.99)$ & $(321.33)$ & $(338.18)$ & $(362.01)$ & $(394.19)$ \\
\hline Two hand weeding (20 and 40 & 4.55 & 4.66 & 11.58 & 12.23 & 14.08 & 14.68 & 15.34 & 15.69 \\
\hline DAS) & $(20.21)$ & $(21.21)$ & $(133.67)$ & $(149.18)$ & $(197.82)$ & $(215.04)$ & $(234.84)$ & $(245.75)$ \\
\hline Azimsulfuron@30g/ha + & 4.63 & 4.72 & 11.65 & 12.30 & 14.20 & 14.73 & 15.46 & 15.84 \\
\hline Bispyribac-sodium @ 25 g/ha & $(20.92)$ & $(21.82)$ & $(135.31)$ & $(150.69)$ & $(201.03)$ & $(216.40)$ & $(238.45)$ & $(250.48)$ \\
\hline Pendimethalin $f b$ Bispyribac- & 3.52 & 3.66 & 10.15 & 10.43 & 11.63 & 12.44 & 13.62 & 14.01 \\
\hline sodium @ $25 \mathrm{~g} / \mathrm{ha}$ & $(11.87)$ & $(12.89)$ & $(102.62)$ & $(108.28)$ & $(134.81)$ & $(154.19)$ & $(184.91)$ & $(195.67)$ \\
\hline SEm \pm & 0.04 & 0.03 & 0.04 & 0.04 & 0.05 & 0.04 & 0.06 & 0.05 \\
\hline $\mathrm{CD}(\mathrm{P}=\mathbf{0 . 0 5})$ & 0.13 & 0.08 & 0.11 & 0.13 & 0.16 & 0.12 & 0.19 & 0.16 \\
\hline
\end{tabular}

Figures in the parentheses are original values 
Table.2 Influence of mulching, nitrogen levels and weed management practices on weed control efficiency $(\%)$ at different growth Stages and weed index $(\%)$ of direct seeded rice

\begin{tabular}{|c|c|c|c|c|c|c|c|c|}
\hline \multirow[t]{3}{*}{ Treatments } & \multicolumn{8}{|c|}{ Weed control efficiency $(\%)$} \\
\hline & \multicolumn{2}{|c|}{30 DAS } & \multicolumn{2}{|c|}{60 DAS } & \multicolumn{2}{|c|}{90 DAS } & \multicolumn{2}{|c|}{ At harvest } \\
\hline & 2014 & 2015 & 2014 & 2015 & 2014 & 2015 & 2014 & 2015 \\
\hline \multicolumn{9}{|l|}{ Mulching } \\
\hline No mulch & 36.22 & 34.82 & 33.30 & 29.84 & 29.77 & 27.03 & 25.14 & 27.35 \\
\hline $\begin{array}{l}\text { Live mulch (Brown manuring with } \\
\text { Sesbania) }\end{array}$ & 58.57 & 61.10 & 38.77 & 40.13 & 37.19 & 36.39 & 33.95 & 34.89 \\
\hline \multicolumn{9}{|l|}{ Nitrogen level $\left(\mathrm{kg} \mathrm{ha}^{-1}\right)$} \\
\hline 120 & 54.87 & 55.31 & 43.01 & 42.08 & 37.55 & 36.50 & 36.09 & 37.20 \\
\hline 150 & 44.66 & 44.86 & 33.59 & 32.04 & 32.53 & 29.99 & 27.08 & 28.45 \\
\hline 180 & 42.65 & 43.70 & 31.51 & 30.83 & 30.35 & 28.63 & 25.48 & 27.71 \\
\hline \multicolumn{9}{|l|}{ Weed management practices } \\
\hline Weedy & 0.00 & 0.00 & 0.00 & 0.00 & 0.00 & 0.00 & 0.00 & 0.00 \\
\hline Two hand weeding (20 and 40 DAS) & 57.89 & 58.97 & 43.93 & 41.50 & 38.44 & 36.41 & 35.13 & 36.46 \\
\hline $\begin{array}{l}\text { Azimsulfuron@30 g/ha + Bispyribac- } \\
\text { sodium @ } 25 \mathrm{~g} / \mathrm{ha}\end{array}$ & 56.41 & 57.79 & 43.24 & 40.90 & 37.44 & 36.01 & 34.13 & 37.66 \\
\hline $\begin{array}{l}\text { Pendimethalin } f b \text { Bispyribac-sodium @ } 25 \\
\text { g/ha }\end{array}$ & 75.27 & 75.07 & 56.96 & 57.54 & 58.05 & 54.41 & 48.92 & 50.36 \\
\hline
\end{tabular}




\section{Weed control efficiency}

A thorough analysis of the data relevant to weed control efficiency (Table 2) clearly indicated that brown manuring with sesbania recorded highest weed control efficiency at all the stages of crop growth during both the years. This might be due to smothering effect of dhaincha against weeds plus inhibitory action of 2, 4-D against sedges and broad leaved weeds.

Under various nitrogen levels, nitrogen dose of $120 \mathrm{~kg} \mathrm{ha}^{-1}$ recorded highest weed control efficiency at all the stages of crop growth. This might be due to lower dry matter accumulation of weeds. Lowest weed control efficiency at all the stages of crop growth was recorded with $180 \mathrm{~kg} \mathrm{ha}^{-1}$. The findings are in agreement with the findings of Mishra and Singh (2007).

Under various weed management practices, treatment pendimethalin $f b$ bispyribacsodium @ 25 g/ha showed higher weed control efficiency than other treatments at all the stages of crop growth during both the years. The main reason behind this was high efficiency of pendimethalin and bispyribac against grassy weeds, sedges and broad leaved weeds.

\section{References}

Banga, O., Petiet, J. and Van Bennekom, J. L. Anonymous, 2013. FAOSTAT, http:// faostat3.fao.org/ faostatgateway /go/to /download/ Q/QC/E, (accessed on September.

Anonymous, 2015. Agricultural statistics at a glance, Department of Agriculture Economics and Statistics, Ministry of Agriculture, New Delhi.

Balasubramanian, V., and Hill, JE, 2002. Direct seeding of rice in Asia: emerging issues and strategic research needs for the 21st century, In: Direct seeding: research issues and opportunities, Proceedings of the International Workshop on Direct Seeding in Asian Rice Systems, Strategic Research Issues and Opportunities, Pandey, S, Mortimer, M, Wade, L, Tuong, TP, Lopez, K and Hardy, B (editors), held during 25-28 January 2000 at Bangkok (Thailand), Los Banos (Philippines), International Rice Research Institute, pp, 15-39.

Bhushan, L, Ladha, JK, Gupta, RK, Singh, S, Tirol-Padre, A, Saharawat, YS, Gathala, $M$ and Pathak, H, 2007. Saving of water and labor in a rice-wheat system with no-tillage and direct seeding technologies, Agronomy Journal, 99, (5), 1288-1296.

Farooq, M., Basra, SMA and Wahid, A, 2006. Priming of field-sown rice seed enhances germination, seedling establishment, allometry, and yield, Plant Growth Regulators, 49, 285-294.

Hussain, S., Ramzan, M, Akhter, $M$ and Aslam, M, 2008. Weed management in direct seeded rice, Journal of Animal and Plant Science, 18, (2-3), 86-88.

Jehangir, W.A., Masih, I, Ahmed, S, Gill, MA, Ahmad, M, Mann, RA, Chaudhary, MR and Turral, H, 2005. Sustaining crop water productivity in rice-wheat systems of South Asia: a case study from Punjab Pakistan, In: Draft Working Paper, International Water Management Institute, Lahore, Pakistan.

Marwat, K.B., Saeed, M, Gul, B, Hussain, Z, 2006. Performance of different herbicides in wheat (Triticum aestivum L.) under rainfed conditions of Kohat, Pakistan Journal of Weed Science Research, 12, (3), 163-168.

Mishra, JS and Singh, VP, 2007. Integrated weed management in zero-till directseeded rice (Oryza sativa) - wheat 
(Triticum aestivum) cropping system, Indian Journal of Agronomy, 52, (3), 198- 203.

Rao, A.N., Johnson, DE, Sivaprasad, B, Ladha, JK and Mortimer, AM, 2007. Weed management in direct-seeded rice, Advances in Agronomy, 93, 153255.

Ravisankar, N., Chandrasekaran, B, Raja, R, Din, $M$ and Chaudhuri, SG, 2008. Influence of integrated weed management practices on productivity and profitability of wet seeded rice (Oryza sativa), Indian Journal of Agronomy, 53, (1), 57-61.

Singh, Shailendra, Singh, Govindra, Singh, VP, Singh, AP and Mortimer, AM, 2005. Effect of weed management and crop establishment methods on weed dynamics and grain yield of rice, Indian Journal of Weed Science, 37, (1\&2), 51-57.

Solunke, P.S., Giri, DG and Rathod, TH,
2006. Effect of integrated nutrient management on growth attributes, yield attributes and yield of basmati rice, Crop research, 32, (3), 279-282.

Subbaiah, S.V., 2008. Studies on weed and water management in direct seeded rice. In: Singh, Y., Singh, VP, Chauhan, B, Orr, A, Mortimer, AM, Johnson, DE and Hardy, B, editors. Direct seeding of rice and weed management in the irrigated rice-wheat cropping system of the Indo-Gangetic Plains. Los Banos (Phillippines): International Rice Research Institute, and Pantnagar (India): Directorate of Experiment Station, G.B. Pant University of Agriculture and Technology. Pp.: 177190.

Tripathi, R.S., and Mishra, R, 1971. Phytosociological studies of the crop weed association at Varanasi, Journal of Indian Botanical Society, 50, 142-152.

\section{How to cite this article:}

Gargi Goswami, Yashwant Singh and Santosh Kumar. 2017. Effect of Agronomic Practices and Weed Management Practices on Weed Dry Weight and Weed Control Efficiency in Direct Seeded Rice under Rainfed Condition of Eastern Uttar Pradesh, India. Int.J.Curr.Microbiol.App.Sci. 6(9): 2132-2138. doi: https://doi.org/10.20546/ijcmas.2017.609.262 